\title{
Aikuiskasvatuksen kokeilu- ja kehittämistoiminta
}

Aikuiskasvatus -lehden toimituskunta on keskustellut useaan otteeseen erityisen aikuiskasvatuksen kehittämis- ja kokeiluprojekteja esittelevän teemanumeron julkaisemisesta. Vaikka tällaisia projekteja on toteutettu ja niitä on parhaillaan käynnissä suhteellisen paljon, niin tietojen saanti niistä on ollut melko hankalaa. Käsityksemme on, että projekteista saatujen kokemusten välittäminen laajemmalle yleisölle auttaa kaikkia kehittämistoiminnassa mukana olevia parantamaan ja kehittämään omia projektejaan. Tiedonvälitystä tehostamalla voidaan hyvät ideat levittää nopeasti muidenkin saataville ja koordinoida paremmin jo laajaksi paisunutta kokeilu- ja kehittämistoimintaa. Näin voidaan myös välttää samojen virheiden ja heikkouksien toistuminen uusissa kehittämishankkeissa. Edellä mainituista syistä johtuen lehden toimituskunta päätti tehdä Aikuiskasvatuksen vuoden 1987 ensimmäisestä numerosta erityisen kokeilu- ja kehittämistoimintaa esittelevän teemanumeron.

Erityistä pontta päätöksellemme antoi se, että Wisconsin-Madison yliopiston professori Alan Knox otti viime vuoden puolella yhteyttä suomalaisiin kollegoihinsa pyytäen heiltä apua kansainvälisen aikuiskasvatusprojekteja vertailevan tutkimuksen aineiston keräämisessä. Professori Knoxin tarkoituksena on yhdessä Belgradin yliopiston (Jugoslavia) professorin Dusan Savićević kanssa koota ja analysoida eri maissa toteutettuja aikuiskoulutusprojekteja ja julkaista niistä myöhemmin vertaileva tutkimusraportti. Kussakin maassa projektiesittelyjen keräämisestä huolehtii ns. koordinaattori (Suomen koordinaattorina toimii allekirjoittanut). Tällä hetkellä kansainvälisessä projektissa on mukana noin 40 maata.

Suomessa projekteja koskevien tietojen kokoaminen on päätetty toteuttaa siten, että esittelyt julkaistaan ensin Aikuiskasvatuksessa ja niistä kansainvälisesti mielenkiintoisimmat julkaistaan myöhemmin englanninkielisinä Adult Education in Finland -lehdessä. Tämä materiaali toimitetaan välittömästi myös professori Alan Knoxille hänen vertailututkimustaan varten.

Aineiston keräämistä varten Aikuiskasvatuksen toimituskunta lähetti projektiesittelypyynnön parillekymmenelle sellaiselle organisaatiolle tai henkilölle, joiden tiedettiin olevan mukana kokeilu- ja kehittämistoiminnassa. Lisäksi lähetekirjelmässä pyydettiin, että vastaanottajat toimittivat tiedot teemanumerosta myös muille sellaisille tahoille, jotka ovat mahdollisesti mukana tällaisessa toiminnassa. Valitettavasti kaikki kokeilutoiminnassa mukana olevat eivät ehtineet työ- ym. kiireidensä takia laatia pro- 
jektiesittelyjä. Jotkut artikkelit sisältävät kuitenkin kuvauksen useammastakin projektista, joten projektien lukumäärä on suurempi kuin artikkeleiden lukumäärä.

Valtakunnallinen kokeilu- ja kehittämistoiminta on meillä organisoitu pitkälti kouluhallituksen ja ammattikasvatushallituksen kautta. Tästä syystä lehdessä luodaan yleiskatsaus näiden tahojen käynnistämään kehittämistoimintaan sekä esitellään lähemmin joitakin näistä projekteista. Muita keskeisiä kokeilu- ja kehittämistoiminnan käynnistäjiä ovat olleet lääninhallitusten kouluosastot, yliopistot, kunnat sekä yritykset. Valitettavasti viimeksimainitun tahon toiminnasta ei saatu juuri palautetta, vaikka yrityksissä harjoitetaankin runsaasti tällaista toimintaa. Vika saattaa olla tiedotuksessa tai sitten siinä, että nämä tahot katsovat oman kehittämis- ja kokeilutoimintansa "liikesalaisuudeksi", joten siitä ei ole tahdottu kertoa laajemmalle lukijakunnalle.

Kun kokeilu- ja kehittämistoimintaan uhrataan Suomessakin jo nykyisin huomattavia rahasummia, niin jatkossa tulisi niiden seurantaan ja hyväksikäyttöön kiinnittää enemmän huomiota. Kenenkään etu ei ole, että toteutetut projektit jäävät kertakokeiluksi. Niiden tuloksista pitäisi tiedottaa myös jatkossa mahdollisimman hyvin, jotta toimintaan uhratut varta tulisivat mahdollisimman hyvin käytetyksi. Tästä syystä kokeilu- ja kehittämistoiminnan seurantaa ja tiedotusta tulisi tehostaa. Parhaiten tämä tehtävä ilmeisesti sopisi Aikuiskoulutusneuvoston toimenkuvaan.

Kokeilu- ja kehittämistoiminnan pitäisi perustua aina tieteelliseen tutkimukseen. Tästä syystä yliopistojen tulisi olla enemmän mukana tässä toiminnassa. Sellaisten tutkijoiden, jotka osallistuvat aktiivisesti kokeilu- ja kehittämistoimintaan, pitäisi saada käyttää osa opetus- ja työvelvollisuudestaan siihen.

Kokeilu- ja kehittämistoimintaan osallistuminen edellyttää tutkijoilta paitsi perinteisen kvantitiivisen tutkimustavan myös entistä enemmän kvalitatiivisen tutkimuksen lähestymistapojen tuntemusta. Kiinnostus jälkimmäiseen lähestymistapaan onkin viime vuosina selvästi lisääntynyt tutkijoiden keskuudessa. Tämä antaa hyvän lähtökohdan heidän osallistumiselleen kokeilu- ja kehittämistoimintaan. Useimmiten kokeilutoiminta on luonteeltaan lähinnä toimintatutkimusta. Vain harvoin ja poikkeustapauksissa voidaan kokeilutoiminnassa käyttää perinteistä koeasetelmaa, koska käytännön tilanteet ovat monimutkaisia ja niihin vaikuttavat monet sellaiset tekijät, joita ei voida kontrolloida.

Käytännön kenttätyössä mukana olevat aikuiskasvattajat tarvitsisivat myös enemmän tietoa kvalitatiivisista tutkimusmenetelmistä, jotta he kykenisivät paremmin osallistumaan kokeilutoimintaan. Tästä syystä heille tulisi järjestää mahdollisimman pian tällaista koulutusta.

Jukka Tuomisto 


\section{AIKUISKASVATUS}

\section{The Finnish Journal of Adult Education \\ Vol. 7, 1-2/1987 \\ ISSN 0358-6197 \\ Summary}

Tuomisto, Jukka 1987. Experimental and development work in adult education.

- The editorial deals with the purpose and contents of this edition of the journal which is dedicated to experimental and development work in adult education. This edition origins can be traced back to a need to provide information on the numerous experimental and development projects being conducted in the field of adult education in Finland. Another factor related to the publication of this edition is the comparitive study of adult education projects in various countries being conducted by prof. Alan Knox of Wisconsin-Madison University.

In Finland the nationwide experimental and development work in adult education is organized to a great extent by the National Board of General Education and the National Board of Vocational Education. For this reason this edition provides an overview on the development projects as well as more detailed presentations of some of these projects. Other significant bodies which initiate experimental and development projects include provincial education departments, universities, municipalities, and enterprises. It is regrettable that information regarding the activities of enterprises is hard to come by even though a great deal of this kind of activity goes on in enterprises.

Experimental and development work should always be based on scientific research. Thus, universities should be involved in it more than they have been so far. Research workers who take an active part in experimental and development work should be entitled to use a part of the time allocated for teaching and research in this manner. Participation in experimental and development work presupposes on the part of the researchers familiarity, not only with traditional quantitative research approaches, but also with qualitative research. Reasearchers have, in fact, shown increasing interest in the latter research approach during the past few years. This provides them with a good starting point for participating in experimental and development work.
Generally, experimental works is by nature more in the line of activity study than quantitative research. It is quite seldom that traditional experiment layouts can be employed in experimental work; this is due to the fact that practical situations are complex and they are acted upon by many different factors. Adult educators in the field are also in need of more information concerning qualitative research methods in order to be in a better position to participate in experimental work. This is why they should be exposed to this type of training as soon as possible.
Translated by Erkki Pekkinen 